\title{
Characterization of the mRNA untranslated regions [UTR] of the Trypanosoma cruzi LYT1 isoforms derived by alternative trans-splicing
}

\author{
Elizabeth Ruíz ${ }^{1}$, César Augusto Ramírez ${ }^{1}$ Julián Camilo Casas ${ }^{1}$, María Isabel Ospina ${ }^{1}$, \\ José María Requena ${ }^{2}$, Concepción J. Puerta ${ }^{1, *}$
}

Edited by

Juan Carlos Salcedo-Reyes

(salcedo.juan@javeriana.edu.co)

1. Laboratorio de Parasitología

Molecular. Departamento de

Microbiología. Facultad de Ciencias.

Pontificia Universidad Javeriana.

Bogotá, Colombia.

2. Centro de Biología Molecular

Severo Ochoa, Universidad Autónoma

de Madrid, Madrid, España.

*cpuerta@javeriana.edu.co

Received: 07-02-2018

Accepted: 17-07-2018

Published on line: 25-09-2018

Citation: Ruíz E, Ramírez CA, Casas JC, Ospina MI, Requena JM, Puerta CM. Characterization of the mRNA untranslated regions [UTR] of the Trypanosoma cruzi LYT1 isoforms derived by alternative trans-splicing, Universitas Scientiarum, 23 (2): 267-290, 2018. doi: $10.11144 /$ Javeriana.SC23-2.cotm

Funding:

This work was supported by

COLCIENCIAS research project ID

PPTA 120356933228, "Caracterización

de factores proteicos asociados a la

regulación de la proteína mLYT1

de Trypanosoma cruzi" granted to CJP. ERM and JCC were supported by COLCIENCIAS convocatoria doctorados nacionales 647-2014 and convocatoria jóvenes investigadores e innovadores 645-2015, respectively.

Electronic supplementary material: Suppl. 1-8.

OPEN ACCESS

\begin{abstract}
In trypanosomatids, gene expression is mainly regulated at posttranscriptional level, through mechanisms based on the interaction between RNA Binding Proteins [RBPs] and motifs present in the untranslated regions [UTRs] of the mRNAs, which altogether form ribonucleoproteic complexes [RNP] that define the fate of the mRNA. The pre-mRNA derived from the LYT1 gene of Trypanosoma cruzi, is processed by alternative trans-splicing, resulting in different mRNAs which code for the isoforms mLYT1 and kLYT1, proteins having differential expression, cellular location and function. The aim of this study was to characterize the 5' and 3' UTRs of the LYT1 mRNAs as the initial step towards the objective of identification of the RBPs responsible for their differential expression. The presence of the two types of 5' UTRs were confirmed in two T. cruzi isolates belonging to the DTU I, thus, corroborating the occurrence of alternative trans-splicing also in the LYT1 gene of this T. cruzi DTU. In addition, for the first time, was unscovered the existence of two types of $L Y T 1$ mRNAs transcripts, differing in length by $116 \mathrm{nts}$, that are generated by alternative polyadenylation. Furthermore, an in-silico analysis of the experimentally obtained UTRs, and ten additional LYT1 sequences retrieved from TritrypDB and GenBank databases, together with a thoroughly search of structural motifs, showed a remarkable conservation of relevant structural motifs previously associated with RNA metabolism in the different UTRs; these elements might be involved in the differential stage-specific expression of each $L Y T 1$ isoform.
\end{abstract}

Keywords: Trypanosoma cruzi; Untranslated region [UTR]; RNA binding proteins [RBP]; Regulation of gene expression; LYT1 gene.

\section{Introduction}

Trypanosoma cruzi is the etiological agent of Chagas disease, an illness recognized for the World Health Organization [WHO] as one of the today seventeen-neglected tropical diseases [NTDs]. Indeed, this disease is a worldwide public health problem, with a current prevalence of 6 to 7 million of infected people, of which 0.7 to 1.2 million are in Colombia $[1,2]$. 
Like other medically important trypanosomatids, T. cruzi has a complex life cycle that must alternate between two types of hosts: insect triatomines and mammals, including humans [3]. To accomplish it, parasites must face and adapt to their hosts' environments through a fine and delicate regulation of their gene expression. In these organisms, gene expression is largely regulated at the posttranscriptional level because of their special gene arrangement, in which large clusters comprising up to hundreds of genes and having the same transcriptional orientation, are constitutively expressed as polycistronic RNA precursors [4-7]. These polycistronic RNAs are ultimately processed into individual molecules through the addition of a Spliced Leader [SL], a common miniexon sequence present in all the mature mRNAs of trypanosomatids, to the 5' end and a poly [A] tail to the 3' end, processes known as trans-splicing and polyadenylation, respectively [8]. In this way, the mechanisms that govern mRNA expression basically operate at the maturation, transport, stability and translation steps through the recognition of RNA motifs, mainly located on the untranslated regions [UTR] of mRNAs, by RNA Binding Proteins [RBP]; both types of molecules, mRNAs and RBP, conform ribonucleoprotein complexes [RNP], which define the fate of the mRNA molecules $[4-6,9,10]$.

In trypanosomatids, it has also been demonstrated the existence of alternative trans-splicing in which two or more mature transcripts are generated from the same gene by the use of different trans-splicing acceptor sites. The relevance of alternative trans-splicing is well illustrated in regards with the functional expression of the $L Y T 1$ protein, a virulence factor of $T$. cruzi $[11,12]$. This protein was uncovered in a pioneer study by Dr Andrews' group in which it was described the existence in T. cruzi of a secreted protein, immunologically related to the $\mathrm{C} 9$ component of the membrane attack complex of complement, that possesses membrane pore-forming activity at low $\mathrm{pH}$ [13]. Given this activity, it was postulated that this protein would be mediating the escape of T. cruzi from the phagosome into the cytosol after cell invasion. Subsequently, Manning-Cela et al. [14], in an outstanding work, undertook the search for the coding gene of this virulence factor by immunoscreening of a T. cruzi cDNA expression library using antibodies against the $\mathrm{C} 9$ component. As a result, the $L Y T 1$ gene was identified and cloned. These authors, furthermore, demonstrated the cytolytic activity of the $L Y T 1$ protein by transfecting Schizosaccharomyces pombe with the $L Y T 1$ gene and analyzing its hemolytic effect [14]. Accordingly, deletion of $L Y T 1$ resulted in attenuation of $T$. cruzi infection capacity; however, unexpectedly, the LYT1-deficient epimastigotes transformed into metacyclic trypomastigotes more rapidly than wild-type parasites. Thus, a double function was suggested for LYT1: (i) a pore-forming activity relevant for intracellular survival, and (ii) a regulatory role during stage transition. Interestingly, in a subsequent article [15], these authors suggested the existence of two LYT1 isoforms, each one associated with a distinct 
functional role. These isoforms are originated by alternative trans-splicing events that generate different $L Y T 1$ mRNAs, which are translated in two different proteins: a full-length protein and an N-terminal truncated one. New articles by this group showed that the shorter protein (lacking $28 \mathrm{~N}$-terminal amino acids, named kLYT1) is located at two spots in the mitochondrial kinetoflagellar zone and its presence was consistent with a role in the parasite development, whereas the larger product, mLYT1, localizes on the plasma membrane and would be responsible for its pore-forming function [16, 17].

In terms of the $L Y T 1$ transcripts expression in CL Brener, a Discrete Typing Unit [DTU] VI strain; it is known that the relative abundance of the transcripts varies, within the parasite life cycle, from one stage to another. Indeed, the transcripts that give rise to the mLYT1 isoform represent $65 \%$ of the mRNAs derived from the LYT1 gene in trypomastigotes and amastigotes, whereas only $35 \%$ corresponds to the $k$ LYT1 transcript in these two stages. In contrast, in the epimastigote stage, the $m \mathrm{LYT} 1$ transcript amounts to $10.5 \%$ and the transcript that gives origin to the kLYT1 isoform represents $89.5 \%$ of the mRNAs derived from the LYT1 gene [15]. Accordingly, in epimastigotes, it was observed that the kLYT1 isoform was more abundant than the mLYT1 one [16].

In this work, was carried out a detailed characterization of the 5' and 3' UTRs of the LYT1 mRNAs, as a first step of a project aimed to the identification of RBPs implicated in the modulation of both their expression and alternative trans-splicing rates. In this way, was experimentally determined the sequence of the 5' UTR from both isoforms in two T. cruzi strains belonging to the DTU I and its conservation was analyzed in 11 additional UTRs from parasites belonging to different DTUs. In addition, for the first time, the 3' UTRs of the LYT1 mRNAs were delimitated; interestingly, the existence of two types of transcripts, differing in length by 116 nts and generated by alternative polyadenylation was uncovered. The analysis was completed by a thoroughly search of structural motifs present in the different UTRs.

\section{Materials and methods}

\section{Parasites}

Epimastigotes of Trypanosoma cruzi 058PUJ [18] and D.A [MHOM/CO/2001/D.A.] [19], two DTU I isolates as well as of Y [20], a DTU II strain, were grown on Liver Infusion Tryptose Medium [LIT] supplemented with $10 \%$ of fetal bovine serum [Eurobio, Inc., Les Ulis, France] at $26^{\circ} \mathrm{C}$. Trypomastigotes of the 058PUJ isolate were obtained 
at described elsewhere [21]. In brief, Green Monkey renal fibroblast-like cells (Vero cells; ATCC CCL-81, Manassas, VA) were cultured in DMEM (Eurobio, Les Ulis, France) supplemented with 10\% FBS (Eurobio), 2 mM L-glutamine, $100 \mathrm{U} / \mathrm{ml}$ penicillin, $100 \mathrm{mg} / \mathrm{ml}$ streptomycin, and $0.01 \mathrm{M}$ HEPES (Eurobio, Les Ulis, France). The cells were grown at $37^{\circ} \mathrm{C}$ in a humid atmosphere at $5 \% \mathrm{CO}_{2}$. When Vero cells reached semiconfluence, they were incubated for $10 \mathrm{~h}$ with $T$. cruzi epimastigotes (ratio 1:10, cell:parasites). Trypomastigotes were collected from the culture supernatant of infected Vero cells at $168 \mathrm{~h}$ postinfection. Infection of fresh Vero cells was then conducted with the trypomastigotes using the same infection multiplicity as before. After two additional passages, the trypomastigotes were collected and extensively washed thrice with $1 \times$ PBS (Eurobio Les Ulis, France); finally, parasites were suspended at $1 \times 10^{7}$ parasites per $\mathrm{ml}$ to proceed with DNA or RNA isolation (see next section).

\section{Nucleic acids extraction, PCR and cloning}

Fifteen $\mathrm{ml}$ of epimastigote culture in logarithmic phase $\left(2 \times 10^{7}\right.$ parasites $\left./ \mathrm{ml}\right)$ were harvested to obtain genomic DNA. Total DNA was isolated using the phenol-chloroform-isoamilic alcohol method [22]. Total RNA was obtained from epimastigotes cultured at logarithmic phase and trypomastigotes grown at $1 \times 10^{7}$ cells $/ \mathrm{ml}$, using the TRIzol method [Invitrogen, California, USA] [23]. The first-strand cDNA synthesis was carried out from total RNA using an oligo-dT primer and the Transcriptor first strand cDNA synthesis kit [Roche, Inc., Mannheim, Germany].

The 5' and 3' UTRs, and the upstream and downstream regions of the LYT1 gene were amplified by PCR using different sets of specific primers synthetized by IDT, Inc. [Miami, USA], [Suppl. 1]. One $\mu$, containing 10 to 12 ng of cDNA, for amplification of the UTR regions or $100 \mathrm{ng}$ of genomic DNA for amplification of the intergenic regions, was used. The PCR reaction mixes were performed in a final volume of $20 \mu \mathrm{l}$, containing: $1 \times$ reaction buffer [10 mM Tris-HCl pH 9.0, $50 \mathrm{mM} \mathrm{KCl,} \mathrm{0.1 \%} \mathrm{Triton} \mathrm{X-100],} 1.5 \mathrm{mM}$ $\mathrm{MgCl}_{2}$, dNTPs (0.4 mM each) mix, $0.5 \mu \mathrm{M}$ of each primer, $1.5 \mathrm{M}$ betain, 0.06 units per $\mu \mathrm{l}$ of expand high fidelity Taq polymerase enzyme [Roche, Inc., Mannheim, Germany]. The PCR reactions were carried out in a thermal cycler $\mathrm{C} 1000 \mathrm{Bio}-\mathrm{Rad}$, under the following amplification profile: $95^{\circ} \mathrm{C} / 5 \mathrm{~min}$ [initial denaturation], 39 cycles at $92^{\circ} \mathrm{C} / 30 \mathrm{~s}$, annealing at $48^{\circ} \mathrm{C}-62^{\circ} \mathrm{C} / 30 \mathrm{~s}$ [Suppl. 1] and extension for $1 \mathrm{~min}$ at $72{ }^{\circ} \mathrm{C}$, with a final incubation at $72{ }^{\circ} \mathrm{C}$ for $10 \mathrm{~min}$. 
The amplified fragments were resolved in agarose gels, stained with HydraGreen ${ }^{\text {TM }}$ Safe Dye and visualized under UV light. The RT-PCR or PCR products were excised from gels, purified using Wizard ${ }^{\circledR}$ SV Gel and PCR Clean-Up System [Promega, Inc., Madison, WI, USA] and cloned into the pGEM-T Easy Vector [Promega, Inc., Madison, WI, USA]. The cloned sequences were determined by the sequencing Service of Macrogen Inc., Korea and their authenticity confirmed by comparison with the upstream and downstream sequences surrounding the LYT1 ORF. Finally, the sequences determined in this work were submitted to the GenBank database [Suppl. 2].

\section{In silico analysis of the $L Y T 1 \mathrm{mRNA}$ UTRs of T. cruzi}

By using the genomic sequence of the $L Y T 1$ gene reported in the TritrypDB database [ID code TcCLB.503829.50] as query sequence, a BLAST search was performed in the TrytripDB and GenBank databases, obtaining eleven $L Y T 1$ sequences from different strains and DTUs (see Table 1), [24-30]. Through a multiple alignment using the Clustal Omega program [31], the LYT1 gene sequence was delimited in each of the sequences listed in Table 1.

With the purpose of searching RNA motifs in the twelve UTR regions, firstly, the secondary structure for conserved sequences located in the 5' and 3' UTRs was determined with the LocARNA program [32]. In addition, to identify potential functional RNA motifs, the RegRNA2.0 program [33] was used. Finally, in-silico predicted mRNA structures were generated for each of the twelve analyzed sequences by the RNAstructure program [34]. After gathering all this information, a consensus secondary structure of the functional motifs presents in all the isolates included in the study was generated using the RNAalifold server [35].

\section{Results}

Identification of the 5' UTRs present in the specific mRNAs that code for the $m \mathrm{LYT} 1$ and $k \mathrm{LYT} 1$ isoforms

The mature mRNAs of the $L Y T 1$ gene in the T. cruzi CL Brener strain are generated in vivo by alternative trans-splicing, giving rise to three transcripts differing in their 5' UTRs [15]. Two of them code for the mLYT1 isoform and the other for the kLYT1 one. In order to determine whether or not an alternative trans-splicing for this gene also occurs in other T. cruzi strains, and to delimitate the 5' UTRs (as the first step for identification of LYT1 
Table 1. LYT1 gene sequences reported in T. cruzi isolates

\begin{tabular}{cccc}
\hline Isolate & DTU & Gen ID & References \\
\hline JR cl. 4 & I & KB223000.1† & {$[a]$} \\
\hline Dm28c & I & AYLP01000135† & {$[24]$} \\
\hline Sylvio X10 & I & ADWP02000208† & {$[25]$} \\
\hline 058PUJ & I & JF410862.1† & {$[18]$} \\
\hline Esmeraldo & II & KB205774.1† & {$[26]$} \\
\hline Y & II & AF253317.1† & {$[14]$} \\
\hline CL Brener & VI & TcCLB.503829.50* & {$[27,28]$} \\
\hline Esmeraldo-like & TI & TcChr22-P: & {$[27,28]$} \\
\hline CL Brener No- & TcCLB.508045.40* & {$[29]$} \\
\hline Esmeraldo-like & VI & AF320626.1† & {$[\mathrm{b}]$} \\
\hline CL Brener & VI & KB851398.1† & {$[30]$} \\
\hline Tula cl2 & VI & Tc_MARK_9353* & \\
\hline Marinkelle B7 & Tcbat & & \\
\hline
\end{tabular}

mRNA interacting RBPs), these regions were mapped in two DTU I isolates, taking advantage of the presence of the common SL sequence at the 5'-end of the mRNAs. The results showed that as occurs in epimastigotes from the CL Brener strain, alternative trans-splicing also takes place in epimastigotes from the D.A. isolate and trypomastigotes from the 058PUJ isolate [Suppl. 2], demonstrating that the existence of two mRNAs species ( $k$ LYT1 and $m$ LYT1) derived from the LYT1 gene is a conserved feature among different strains of T. cruzi [Fig. 1a and 1b]. In contrast, it was not found any evidence on the third transcript, previously described in the CL Brener strain, that would correspond to a mRNA (coding for the mLYT1 isoform), which is generated by using a non-canonical GG dinucleotide splicing acceptor site. As shown in Fig. 1a and 1b, the two types of 5' UTRs are well conserved (both in sequence and length) when compared with the equivalent genomic regions in ten different T. cruzi strains (belonging to the DTU-I, II, VI, and Tcbat). A complete sequence alignment is provided as supplementary material, showing the existence of a high sequence conservation [Suppl. 3 and 4]. 
a)

\section{5'UTR}

5' AACUAACGCUAUUAUUGaUACAGUUUCUGUACUAUAUUGUUUC ORF $m$ LYT1 3'UTR

\begin{tabular}{|ccccc|}
\hline Isolate & ID & DTU & Length (nt) & Identity (\%) \\
\hline JR cl4 & KB223000.1 & I & 81 & 92.86 \\
\hline Dm28c & AYLP01000135 & I & 83 & 97.67 \\
\hline Sylvio X10 & ADWP02000208 & I & 81 & 97.62 \\
\hline 058PUJ & JF410862.1 & I & 83 & 100 \\
\hline D.A. & - & I & 84 & 100 \\
\hline Esmeraldo & KB205774.1 & II & 86 & 95.35 \\
\hline Y & AF253317.1 & II & 87 & 97.73 \\
\hline CL Brener Esmeraldo-like & TcCLB.503829.50 & VI & 85 & 97.73 \\
\hline CL Brener no Esmeraldo-like & TcCLB.508045.40 & VI & 85 & 97.73 \\
\hline Tula c12 & AF320626.1 & VI & 86 & 97.76 \\
\hline Marinkellei B7 & KB851398.1 & VI & 85 & 97.62 \\
\hline & Tc_MARK_9353 & Tcbat & 80 & 82.50 \\
\hline
\end{tabular}

b)

\section{5'UTR}

5’AACUAACGCUAUUAUUGAUACAGUUUCUGUACUAUAUUG AAAGCCGCAGCAUUAGUAGCGCCCACAGCAGACUCACGG CCGACGUGCCGCGGGGCUGCCAUUGCGAAUAACUUU-3’

\begin{tabular}{|ccccc|}
\hline Isolate & ID & DTU & Length (nt) & Identity (\%) \\
\hline JR cl4 & KB223000.1 & I & 114 & 98.67 \\
\hline Dm28c & AYLP01000135 & I & 114 & 98.67 \\
\hline Sylvio X10 & ADWP02000208 & I & 114 & 97.33 \\
\hline 058PUJ & JF410862.1 & I & 114 & 100 \\
\hline D.A. & - & I & 114 & 96 \\
\hline Esmeraldo & KB205774.1 & II & 114 & 94.67 \\
\hline Y & AF253317.1 & II & 114 & 94.67 \\
\hline CL Brener Esmeraldo-like & TcCLB.503829.50 & VI & 114 & 97.33 \\
\hline CL Brener no Esmeraldo-like & TcCLB.508045.40 & VI & 114 & 97.33 \\
\hline CL Brener & AF320626.1 & VI & 114 & 97.33 \\
\hline Tula c12 & KB851398.1 & VI & 114 & 94.67 \\
\hline Marinkellei B7 & Tc_MARK_9353 & Tcbat & 114 & 93.33 \\
\hline
\end{tabular}

Figure 1. Sequences of the LYT1 5' UTR mRNA isoforms. [a]. Upper panel: 5' UTR $m$ LYT1 sequence from the 058PUJ (DTU I) isolate (GenBank KT279498). Lower panel: 5' UTR $m$ LYT1 length sequences and sequence identity (using Clustal Omega) among twelve T. cruzi isolates [b]. Upper panel: 5' UTR kLYT1 sequence from the 058PUJ (DTU I) isolate (GenBank ID KT328589). Lower panel: 5' UTR kLYT1 length sequences and sequence identity among twelve T. cruzi isolates The Leader Sequence Leader [SL] common to both 5' UTRs is underlined, and the motifs present in each of the UTRs are highlighted in blue. 


\section{3' UTR sequences of the LYT1 mRNA}

With the aim of determining the 3' UTR of the LYT1 mRNA, this region was initially amplified using RNA from epimastigotes and trypomastigotes of the 058PUJ isolate [Fig. 2]. Unexpectedly, three amplification products were clearly observed in both epimastigote and trypomastigote RNA samples. After cloning of the PCR products from the epimastigote sample, two different fragments were cloned, named here 3' UTR-I and 3' UTR-II, that after sequencing were found to be 264 and 380 nucleotides in length, respectively, without taking into account the poly (A) sequence [Fig. 3a and 3b]. Similar results were obtained when RNA from epimastigotes of the D.A

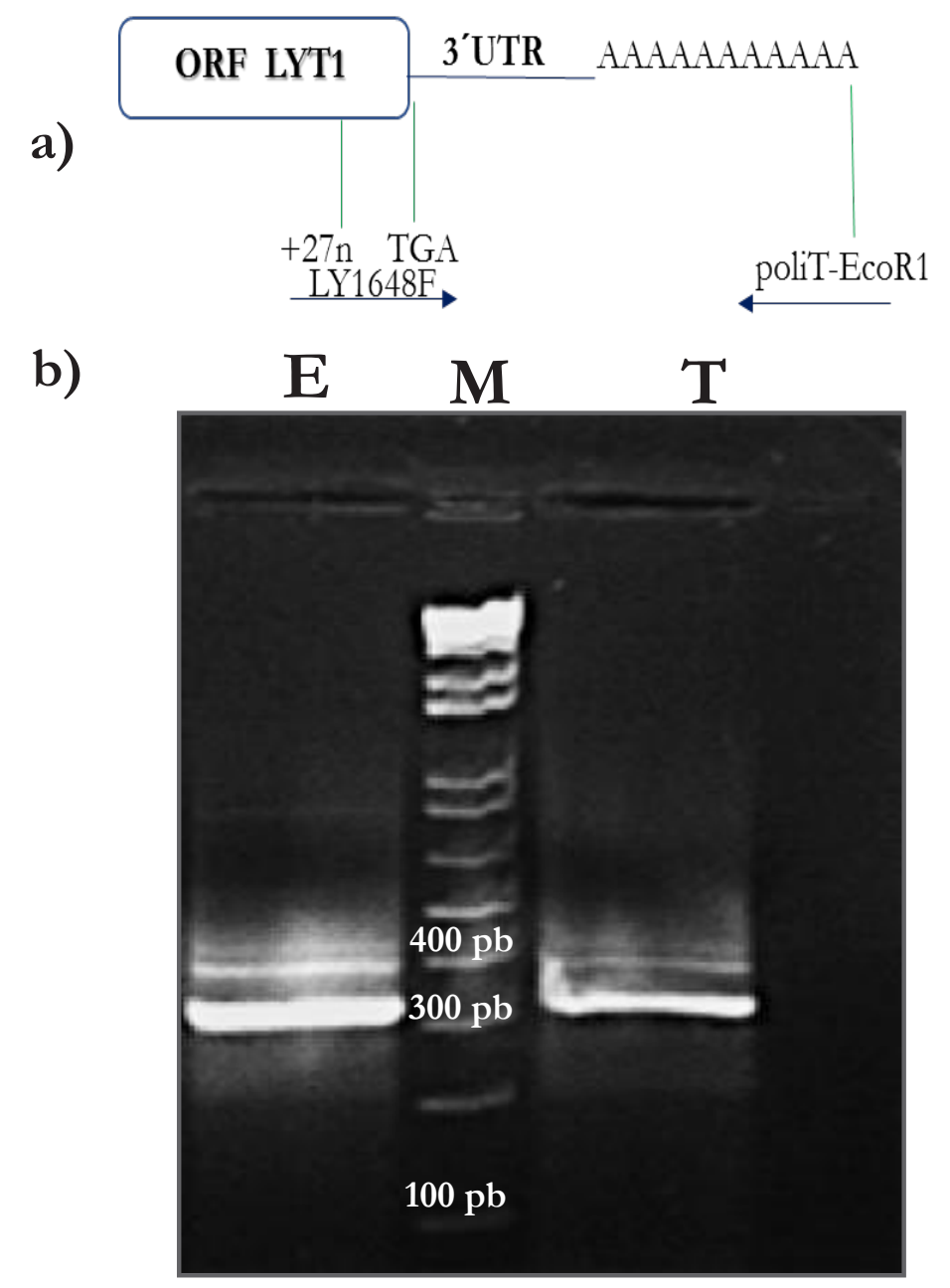

Figure 2. Amplification from complementary DNA (cDNA) of the 3' UTR of $L Y T 1$ of $T$. cruzi isolate 058PUJ by conventional PCR [a]. Upper panel: Schematic representation of the cloning strategy. [b]. Lower panel: cDNA from epimastigotes [lane E], Molecular Weight Marker $1 \mathrm{~Kb}$ plus Invitrogen ${ }^{\mathrm{TM}}$ [lane $\mathrm{M}]$, cDNA from trypomastigotes [lane T]. 
a)

3'UTR-I

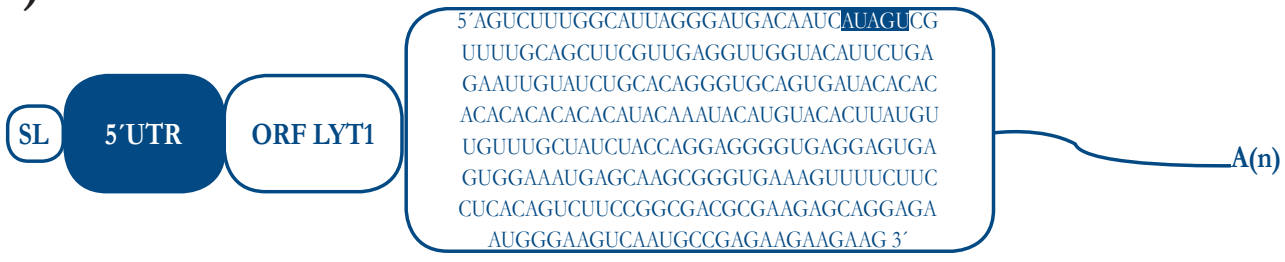

\begin{tabular}{|c|cccc|}
\hline Isolate & ID & DTU & Length (nt) & Identity (\%) \\
\hline JR c14 & KB223000.1 & I & 262 & 100 \\
\hline Dm28c & AYLP01000135 & I & 262 & 100 \\
\hline Sylvio X10 & ADWP02000208 & I & 262 & 100 \\
\hline 058PUJ & JF410862.1 & I & 264 & 100 \\
\hline D.A. & - & I & 259 & 100 \\
\hline Esmeraldo & KB205774.1 & II & 257 & 95.70 \\
\hline Y & AF253317.1 & II & 259 & 95.00 \\
\hline CL Brener Esmeraldo-like & TcCLB.503829.50 & VI & 256 & 94.53 \\
\hline CL Brener no Esmeraldo-like & TcCLB.508045.40 & VI & 256 & 94.53 \\
\hline CL Brener & AF320626.1 & VI & 264 & 93.51 \\
\hline Tula c12 & KB851398.1 & VI & 270 & 95.42 \\
\hline Marinkellei B7 & Tc_MARK_9353 & Tcbat & 249 & 88.76 \\
\hline
\end{tabular}

b)

3'UTR-II

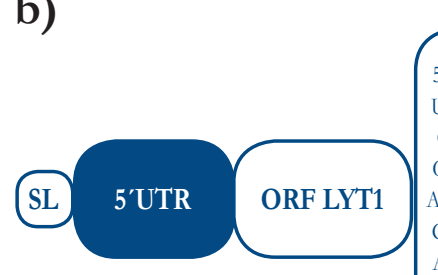

'AAUCCUUAGCAUUAGGGAUGACAAUCAUAGUCGUUUGCAGCU UCGUUAAGGUUGGUACCUUCAGAGAAUUGUAUCUGCACCCUGL GCAGUGAUACACACACACACAUACAAAUACAUGUACACUUAUGU CUUUUGCUAUCUACCAGGAGGGGCGAGGAGUGAGUGGAAAUG AGCAAGCCGGGUGAAAGCUUUCUUCCUCACAAUCUCCCGGCGAC GCGAAGAGCAGGAGGAGGGAGGUACAAUGCGAGAAGAAGAAG AAGAAGAAAAAAGAAAAAAAAAGAAAGAAGUAAAAUGACGUUC GAGQGUAGUUAAGCAUACCCUUGAGUACACUGAACAGAUAAAC AAACACAAGGGUACAGAAAAAUGAAACGGGAGGG 3'

\begin{tabular}{|ccccc|}
\hline Isolate & ID & DTU & Length (nt) & Identity (\%) \\
\hline JR cl4 & KB223000.1 & I & 376 & 100 \\
\hline Dm28c & AYLP01000135 & I & 377 & 100 \\
\hline Sylvio X10 & ADWP02000208 & I & 373 & 100 \\
\hline 058PUJ & JF410862.1 & I & 380 & 100 \\
\hline D.A. & - & I & 380 & 100 \\
\hline Esmeraldo & KB205774.1 & II & 378 & 95.37 \\
\hline Y & AF253317.1 & II & 381 & 95.02 \\
\hline CL Brener Esmeraldo-like & TcCLB.503829.50 & VI & 376 & 94.59 \\
\hline CL Brener no Esmeraldo-like & TcCLB.508045.40 & VI & 376 & 94.59 \\
\hline CL Brener & AF320626.1 & VI & 384 & 93.58 \\
\hline Tula c12 & KB851398.1 & VI & 382 & 95.47 \\
\hline Marinkellei B7 & Tc_MARK_9353 & Tcbat & 340 & 88.89 \\
\hline
\end{tabular}

Figure 3. Sequences of two 3' UTRs generated from transcription of the LYT1 gene in the 058PUJ (DTU I) isolate. [a]. Upper panel: 3' UTR-I LYT1 sequence (deposited in GenBank under accession number KU973680), and sequence identity in twelve T. cruzi isolates [b]. Lower panel: 3' UTR-II sequence (deposited in GenBank under accession number KU973678) and sequence identity percent in twelve T. cruzi isolates. The motifs present in each of the UTRs are highlighted in blue. 
isolate was used for RT-PCR amplification [suppl. 2]. However, after cloning of the amplification products obtained from the trypomastigote sample, only the fragment corresponding to the 3' UTR-I region, was successfully cloned in the 058PUJ isolate [suppl.2]. Nevertheless, according to the amplification bands observed in both parasite stages [Fig. 2], it might be concluded that both types of 3'-UTRs (and even a third one) are generated in equivalent proportions in epimastigotes and trypomastigotes.

Comparison of the 3' UTR-I with the LYT1 genomic corresponding sequence revealed that downstream at the end of the 3' UTR-I, there exists in the genome a poly (A) stretch [suppl. 5]. Thus, in order to verify the existence of this 3' UTR-I, a new forward primer, the LY3U167F oligonucleotide, priming at nucleotides 167 to 186 from both 3' UTR [suppl. 1], and the ACAC-HindIII-Oligo [DT]25 primer were used in a more astringent RT-PCR reaction. In this way, a $127 \mathrm{bp}$ fragment whose sequence aligned, as expected, with the 96 last nucleotides of the 3' UTR-I sequence was amplified, corroborating the existence of the 3' UTR-I. According to these results, the polyadenylation sites were mapped at positions 1.924 and 2.044 from LYT1 start codon of the CL Brener isolate [GenBank ID AF320626.1].

Similar to the 5' UTRs, both 3' UTR regions are well conserved among different parasite isolates [Fig. $3 \mathrm{a}$ and $3 \mathrm{~b}$ ]. Nonetheless, some micro heterogeneity, including transitions, transversions and insertions/deletions, were observed at some places within these regions [suppl. 6 - 9].

\section{Identification of conserved RNA motifs in the LYT1 mRNA UTRs}

Once, each of the LYT1 gene sequences listed in Table 1 were delimited, the hypothetical 5' UTR of each isoform was located using the trans-splicing signals: the AG dinucleotide acceptor of the leader sequence [SL] and the polypyrimidine tract. Meanwhile, the delimitation of the LYT1 3' UTR was based on the location of the TGA stop codon [suppl. 5]. In addition, to confirm these results, a sequence comparison was performed using the experimentally obtained UTR regions and equivalent genomic regions present in databases.

Following the pipeline described in Materials and Method section, several motifs were found in each UTR region of the different LYT1 mRNAs: two in the 5' UTR $m$ LYT1, one in the 5' UTR kLYT1, one in the 3' UTR-I and two in the 3' UTR-II. Of note, the predicted motifs were different according to the UTR length. Indeed, a Sex-Lethal binding site $(\mathrm{Sxl})$ and a Guanine rich region 
Table 2. Functional motifs present in the 5' and 3' UTRs of the mRNA of $m \mathrm{LYT} 1$ and $k$ LYT1 isoforms 058PUJ.

\begin{tabular}{|c|c|c|c|c|}
\hline UTR & Name motif & Sequence motif & $\begin{array}{c}\text { Position } \\
\text { (nt)motif } \\
\text { in UTR } \\
\text { region }\end{array}$ & References \\
\hline \multirow{2}{*}{$\begin{array}{l}\text { 5' UTR } \\
\text { mLYT1 }\end{array}$} & Sxl binding site & $\mathrm{U}[\mathrm{n}]$ & $50-60$ & [36] \\
\hline & Guanine rich motif & GUGGCCGUGCUCGC & $66-79$ & {$[37,38]$} \\
\hline $\begin{array}{l}5^{\prime} \mathrm{UTR} \\
\text { kLYT1 }\end{array}$ & $\begin{array}{l}\text { Musashi binding } \\
\text { element }\end{array}$ & AUUAGU & $51-56$ & {$[39,40]$} \\
\hline $\begin{array}{l}3^{\prime} \text { UTR-I } \\
\text { and II }\end{array}$ & $\begin{array}{l}\text { Musashi binding } \\
\text { element }\end{array}$ & AUAGU & $27-31$ & {$[39,40]$} \\
\hline \multirow{2}{*}{ 3' UTR-II } & UNR binding site & GAAAGAAGUAA & $279-289$ & [41] \\
\hline & $\begin{array}{l}\text { Musashi binding } \\
\text { element }\end{array}$ & GUAGU & 304-308 & {$[39,40]$} \\
\hline
\end{tabular}

(G) were found in the 5'UTR mLYT1 region. Meanwhile, in the 5' kLYT1 and 3' UTR regions, a Musashi binding element, having a nucleotide variation between them, was detected. Besides this Musashi binding element common to both 3' UTR regions, located within the last 116 nucleotides of the 3'UTR-II region, an Upstream of N-ras (UNR) element was predicted. All these motifs are commonly found in mRNAs from different eukaryotic organisms [36-41]. Table 2 lists the motifs identified and [suppl. 10] shows their structures and location within the predicted secondary structure of the two types of UTRs.

\section{Discussion}

Similar to alternative cis-splicing existing in most eukaryotes, alternative trans-splicing events may represent a source for protein diversity in trypanosomatids, including those with complex life cycles such as $T$. cruzi [42-44]. An example of this is the LYT1 gene, which codes for two protein isoforms, mLYT1 and kLYT1, whose expression is directed by an alternative trans-splicing occurring during the processing of the primary gene transcript $[14,15]$. This mechanism of gene expression gives rise to two protein isoforms that only differ in 28 out of the 552 aa comprising the larger isoform. Moreover, differences in the regulatory regions (i.e. UTRs) of the transcripts, through their interactions with a set of ribonucleoproteic complexes, are also linked to different cellular expression patterns, subcellular location and temporal 
function [45-47]. In this context, as the initial step within the project aimed to the identification of trans-acting regulatory proteins involved in the differential expression of $L Y T 1$ transcripts, in this work were precisely mapped the 5' and 3' UTRs of the LYT1 mRNAs. Thus, the existence of the LYT1 alternative trans-splicing event, previously reported for the CL Brener, a VI DTU isolate [15], was also confirmed in two DTU I T. cruzi isolates. This remarkable evolutionary conservation supports the importance of both isoforms for the parasite development and infectivity, independently of the parasite DTU $[14,16]$. Accordingly, the length and sequence of this region is well conserved among the different parasite DTUs analyzed. Moreover, in-silico analysis regarding the $L Y T 1$ presence in other organisms revealed that it is only present in the Trypanosoma genus (data not shown).

The UTRs, mainly the 3' UTR regions, have been shown to play crucial roles in the posttranscriptional mechanisms of gene regulation [48]. Indeed, the knowledge and regulatory elements annotation of these regions could get insights into their role. In this work, was clearly demonstrated the existence in epimastigotes of two different 3' UTRs in the LYT1 mRNAs that result from the use of different polyadenylation sites. In trypomastigotes, even though the fragment corresponding to the 3' UTR-II could not be cloned, its existence is not ruled out by taking into account the RT-PCR results shown in Fig. 2. Alternative polyadenylation, which has been extensively described in all eukaryotic species, is a major mechanism of gene regulation, influencing both mRNA abundance and location [49,50]. Given the particular localization and differential expression of each $L Y T 1$ isoform, it is possible that each isoform derives from a transcript carrying a particular 3' UTR. There are many examples showing the relevant role played by alternative 3' UTRs as scaffolds to regulate protein location. For instance, the human CD47 protein is expressed from two mRNAs differing in the length of the 3' UTR; the longest one facilitates its localization on the cell surface, and the shortest modulates its localization in the endoplasmic reticulum [50].

In trypanosomatids, gene expression is regulated at posttranscriptional level through mechanisms based on the interaction between RBPs and motifs, mostly present in the UTR regions [51, 52]. Therefore, herein was searched for functional RNA motifs present in the different UTR regions identified in this work. As a result, several motifs in each type of UTR were found. Indeed, for the 5' UTR $m$ LYT1 two motifs were found. One of them, a guanine rich motif that has been described in other organisms as mediator a repressor effect on mRNA translation [38]. The other, a Sxl element, composed mainly of uracils, enhances the mRNA expression when present at the 5' UTR of genes in tobacco plants and Drosophila [36, 53]. Regarding the 5' UTR kLYT1, a Musashi element was detected. These cis-elements regulate, positively or 
negatively, the translation of $\mathrm{mRNAs}$ through its recognition by specific RBPs that bind to the UAG core $[54,55]$. Interestingly, its presence was also observed in both types of LYT1 3' UTRs. Meanwhile, the UNR motif, exclusive of the LYT1 3'UTR-II region, has been related to the destabilization of the mRNAs in mammals; this rich purine motif is bound by RBPs in RNP complexes that are engaged in rapid deadenylation of mRNAs [41].

Taking into account the different motifs identified in the LYT1 UTRs and the roles played in other organisms, it can be hypothesized the following regulatory model: The Sxl element would have a positive regulation on the $m L Y T 1$ transcript in the trypomastigote stage whereas at the epimastigote stage this transcript would be down regulated by the $\mathrm{G}$ rich motif. In the same way, the Musashi elements would be positively regulating the mRNA expression of the $k L Y T 1$ transcript at the epimastigote stage. Meanwhile, the UNR elements would be exerting a repressor effect on its translation at the trypomastigote stage. In addition, independently of the precise function of each of these motifs, surely they could have a pivotal role on the LYT1 isoforms expression.

\section{Conclusion}

The occurrence of $L Y T 1$ trans-splicing in the parasite DTU I was confirmed, and predicted its existence in the parasite DTUs II, VI and Tcbat. For the first time, the 3' UTR of the LYT1 mRNA was mapped showing two polyadenylation sites that give rise to two transcripts differing in $116 \mathrm{nts}$, which could have different roles on the location and expression patterns for each isoform. Moreover, different functional motifs associated with RNA metabolism have been identified in each one of the UTRs, and its potential involvement in the differential parasite-stage expression of each isoform has been discussed.

\section{Acknowledgements}

This work was supported by COLCIENCIAS research project ID PPTA 120356933228, "Caracterización de factores proteicos asociados a la regulación de la proteína mLYT1 de Trypanosoma cruzi” granted to CJP. ERM and JCC were supported by COLCIENCIAS convocatoria doctorados nacionales 647-2014 and convocatoria jóvenes investigadores e innovadores 645-2015, respectively.

\section{Conflicts of interests}

Authors declare that there are no conflicts of interest related to the results obtained in this study. 


\section{References}

[1] Instituto Nacional de Salud [INS]. Proceso de vigilancia y análisis del riesgo en salud pública. Informe del evento enfermedad de Chagas, Colombia. 1-16, 2017.

Retrieved from: http://simposiovirologia.ins.gov.co/lineas-de accion/ Subdireccion-Vigilancia

[2] Organización Mundial de la Salud [OMS]. Nota descriptiva $\mathrm{N}^{\circ} 340$. La enfermedad de Chagas [Tripanosomiasis americana]. 2017.

Retrieved from www.who.int/mediacentre/factsheets/fs340

[3] Bern C. Chagas' Disease, New England Journal of Medicine, 373(5): 456-466, 2015.

doi: 10.1056/NEJMra1410150

[4] Araújo P, Teixeira S. Regulatory elements involved in the posttranscriptional control of stage-specific gene expression in Trypanosoma cruqi: a review, Memórias do Instituto Oswaldo Cruz, 106(3): 257-266, 2011.

doi: 10.1590/S0074-02762011000300002

[5] Cassola A, Frasch A. An RNA recognition motif mediates the nucleocytoplasmic transport of a Trypanosome RNA-binding protein, Journal of Biological Chemistry, 284(50): 35015-35028, 2009. doi: 10.1074/jbc.M109.031633

[6] Clayton C, Shapira M. Post-transcriptional regulation of gene expression in trypanosomes and leishmanias, Molecular and Biochemical Parasitology,156(2): 93-101, 2007.

doi: 10.1016/j.molbiopara.2007.07.007

[7] Martínez-Calvillo S, Vizuet-de-Rueda J, Florencio-Martínez L, Manning-Cela R, Figueroa-Angulo E. Gene expression in trypanosomatid parasites, Journal of Biomedicine and Biotechnology, 2010(525241): 1-15, 2010.

doi: 10.1155/2010/525241

[8] Günzl A. The pre-mRNA splicing machinery of trypanosomes complex or simplified?, Eukaryotic Cell, 9(8): 1159-1170, 2010.

doi: 10.1128/EC.00113-10 
[9] Glisovic T, Bachorik J, Yong J, Dreyfuss G. RNA-binding proteins and post-transcriptional gene regulation, FEBS Letters, 582(14): 1977-1986, 2008.

doi: 10.1016/j.febslet.2008.03.004

[10] Lim C, Allada R. Emerging roles for post-transcriptional regulation in circadian clocks, Nature Neuroscience, 16(11): 1544$1550,2013$.

doi: 10.1038/nn.3543

[11] Osorio L, Ríos I, Gutiérrez B, González J. Virulence factors of Trypanosoma cruzi: who is who?, Microbes and Infection, 14(15): 1390-1402, 2012.

doi: 10.1016/j.micinf.2012.09.003

[12] Zago M, Barrio A, Cardozo R, Duffy T, Schijman A, Basombrío M. Impairment of infectivity and immunoprotective effect of a LYT1 null mutant of Trypanosoma cruzi, Infection and Immunity, 76(1): 443-451, 2008.

doi: 10.1128/IAI.00400-07

[13] Andrews N, Abrams C, Slatin S, Griffiths G. A T. cruqi secreted protein immunologically related to the complement component C9: evidence for membrane pore-forming activity at low $\mathrm{pH}$, Cell, 61(7): 1277-1287, 1990.

doi: 10.1016/0092-8674(90)90692-8

[14] Manning-Cela R, Cortés A, González-Rey H, Van Voorhis W, Swindle J, González A. LYT1 protein is required for efficient in vitro infection by Trypanosoma cruzi, Infection and Immunity, 69(6): 3916-3923, 2001.

doi: 10.1128/IAI.69.6.3916-3923.2001

[15] Manning-Cela R, González A, Swindle J. Alternative splicing of LYT1 transcripts in Trypanosoma cruzi, Infection and Immunity, 70(8): 4726-4728, 2002.

doi: 10.1128/IAI.70.8.4726-4728.2002

[16] Benabdellah K, González E, González A. Alternative transsplicing of the Trypanosoma cruzi LYT1 gene transcript results in compartmental and functional switch for the encoded protein, Molecular Microbiology, 65(6): 1559-1567, 2007.

doi: 10.1111/j.1365-2958.2007.05892.x 
[17] Ballesteros G, Santillán M, Cruz M, Márquez C, Lugo C, Martínez S, Swindle J, Manning-Cela R. The alternative products of Trypanosoma cruzi LYT1 have different localization patterns, Veterinaria. México OA, 43(1):29-42, 2012.

[18] Pavía P, Thomas M, Lopez M, Puerta C. Molecular characterization of the short interspersed repetitive element SIRE in the six discrete typing units (DTUs) of Trypanosoma cruzi, Experimental Parasitology, 132(2): 144-150, 2012.

doi: 10.1016/j.exppara.2012.06.007

[19] Barrera Y, Guevara J, Pavía P, Montilla M, Nicholls R, Parra E, Puerta C. Evaluación de las pruebas de PCR TcH2AF-R y S35S36 para la detección de Trypanosoma cruzi en tejido cardiaco de ratón, Biomédica, 28(4):616-626, 2008.

doi: 10.7705/biomedica.v28i4.68

[20] Silva L, Nussenzweig V. Sobre una cepa de Trypanosoma cruzi altamente virulenta para o camundongo branco, Folia Clinica et Biologica, 20(1): 191-207, 1953.

[21] Lasso P, Mateus J, Pavía P, Rosas F, Roa N, Thomas M, López M, González J, Puerta C, Cuéllar A. Inhibitory receptor expression on $\mathrm{CD} 8+\mathrm{T}$ cells is linked to functional responses against Trypanosoma cruzi antigens in chronic chagasic patients, The Journal of Immunology, 195(8): 3748-3758, 2015.

doi: 10.4049/jimmunol.1500459

[22] Sambrook J, Fritsch E, Maniatis T. Molecular cloning: a laboratory manual. Harbor laboratory press, Cold spring harbor, New York. USA, 1989.

[23] Rio D, Ares Jr M, Hannon G, Nilsen T. RNA: a laboratory manual. CSHL press, Cold spring harbor, New York. USA, 2010. doi: $10.1101 /$ pdb.prot5439

[24] Grisard E, Teixeira S, de Almeida L, Stoco P, Gerber A, TalaveraLópez C, Lima O, Andersson B, de Vasconcelos A. Trypanosoma cruzi clone Dm28c draft genome sequence, Genome Announcements, 2(1):1-2, 2014.

doi: 10.1128/genomeA.01114-13

[25] Franzén O, Ochaya S, Sherwood E, Lewis M, Llewellyn M, Miles M, Andersson B. Shotgun sequencing analysis of Trypanosoma cruzi I Sylvio X10/1 and comparison with T. cruzi VI CL Brener, PLoS Neglected Tropical Diseases, 5(3):1-9, 2011.

doi: 10.1371/journal.pntd.0000984 
[26] Miles M, Toye P, Oswald S, Godfrey D. The identification by isoenzyme patterns of two distinct strain-groups of Trypanosoma cruzi, circulating independently in a rural area of Brazil, Transactions of the Royal Society of Tropical Medicine and Hygiene, 71(3): 217-225, 1977.

doi: 10.1016/0035-9203(77)90012-8

[27] Weatherly D, Boehlke C, Tarleton R. Chromosome level assembly of the hybrid Trypanosoma cruzi genome, BMC Genomics, 10(255): 1-13, 2009.

doi: 10.1186/1471-2164-10-255

[28] Lima L, Ortiz P, da Silva F, Alves J, Serrano M, Cortez A, Alfieri S, Buck G, Teixeira M. Repertoire, genealogy and genomic organization of cruzipain and homologous genes in Trypanosoma cruzi, T. cruzi-like and other Trypanosome species, PLoS ONE, $7(6): 1-15,2012$.

doi: 10.1371/journal.pone.0038385

[29] Cosentino R, Aguero F. A simple strain typing assay for Trypanosoma cruzi: discrimination of major evolutionary lineages from a single amplification product, PLoS Neglected Tropical Diseases, 6(7):1-11, 2012.

doi: 10.1371/journal.pntd.0001777

[30] Franzén O, Talavera-López C, Ochaya S, Butler C, Messenger L, Lewis M, Llewellyn M, Marinkelle C, Tyler K, Miles M, Andersson B. Comparative genomic analysis of human infective Trypanosoma cruzi lineages with the bat-restricted subspecies. T. cruzi marinkellei, BMC Genomics, 13(531):1-19, 2012.

doi: 10.1186/1471-2164-13-531

[31] Sievers F, Wilm A, Dineen D, Gibson T, Karplus K, Li W, Lopez R, McWilliam H, Remmert M, Söding J, Thompson J, Higgins D. Fast, scalable generation of high-quality protein multiple sequence alignments using Clustal Omega, Molecular Systems Biology, 7(539):1-6, 2011.

doi: $10.1038 / \mathrm{msb} .2011 .75$

[32] Will S, Joshi T, Hofacker I, Stadler P, and Backofen R. LocARN-P: accurate boundary prediction and improved detection of structural RNAs, RNA, 18(5):900-914, 2012.

doi: $10.1261 /$ rna.029041.111 
[33] Chang T, Huang H, Hsu J, Weng S, Horng J, Huang H. An enhanced computational platform for investigating the roles of regulatory RNA and for identifying functional RNA motifs, $B M C$ bioinformatics, 14(2):1-8, 2013.

Retrieved from http://www.biomedcentral.com/1471-2105/14/S2/S4

[34] http://rna.urmc.rochester.edu/RNAstructureWeb/

[35] Bernhart S, Hofacker I, Will S, Gruber A, Stadler P. RNAalifold: improved consensus structure prediction for RNA alignments, BMC bioinformatics, 9(474): 1-13, 2008.

doi: 10.1186/1471-2105-9-474

[36] Nagao I, Obokata J. A poly(U) motif in the 5'untranslated region enhances the translational efficiency of b-glucuronidase mRNA in transgenic tobacco, Plant Science, 165(2003):621-626, 2003.

doi: 10.1016/S0168-9452(03)00232-2

[37] Kaspar R, Kakegawa T, Cranston H, Morris D, White M. A regulatory cis element and a specific binding factor involved in the mitogenic control of murine ribosomal protein L32 translation, Journal of Biological Chemistry, 267(1):508-514, 1992

PMID: 1309750

[38] Sajjanar B, Deb R, Raina S, Pawar S, Brahmane M, Nirmale A, Kurade N, Manjunathareddy G, Bal S, Singh N. Untranslated regions (UTRs) orchestrate translation reprogramming in cellular stress responses, Journal of Thermal Biology, 65(16):69-75, 2017.

doi: $10.1016 /$ j.jtherbio.2017.02.006

[39] Charlesworth A, Wilczynska A, Thampi P, Cox L, MacNicol A. Musashi regulates the temporal order of mRNA translation during Xenopus oocyte maturation, The EMBO Journal, 25(12):2792-2801, 2006.

doi: 10.1038/sj.emboj.7601159

[40] Lan L, Appelman C, Smith A, Yu J, Larsen S, Marquez R, Liu H, Wu X, Gao P, Roy A, Anbanandam A, Gowthaman R, Karanicolas J, De Guzman R, Rogers S, Aubé J, Ji M, Cohen R, Neufeld K, Xu L. Natural product (-) gossypol inhibits colon cancer cell growth by targeting RNA-binding protein Musashi-1, Molecular Oncology, 9(7):1406-1420, 2015.

doi: 10.1016/j.molonc.2015.03.014 
[41] Chang T, Yamashita A, Chen C, Yamashita Y, Zhu W, Durdan S, Kahvejian A, Sonenberg N, Shyu A. UNR, a new partner of poly (A)-binding protein, plays a key role in translationally coupled mRNA turnover mediated by the c-fos major coding-region determinant, Genes and Development, 10(16):2010-2023, 2004.

doi: $10.1101 / \operatorname{gad} .1219104$

[42] Clayton C. The regulation of trypanosomes gene expression by RNA-binding proteins, PLoS Pathogens, 9(11):1-4, 2013.

doi: 10.1371/journal.ppat.1003680

[43] Day D, Tuite M. Post-transcriptional gene regulatory mechanisms in eukaryotes: on overview, Journal of Endocrinology, 157(3):361-371, 1998.

PMID: 9691970

[44] Gazestani V, Lu Z, Salavat R. Deciphering RNA regulatory elements in trypanosomatids: one piece at a time or genomewide?, Trends in Parasitology, 30(5): 234-240, 2014.

doi: 10.1016/j.pt.2014.02.008

[45] Gomez C, Ramirez M, Calixto-Galvez M, Medel O, Rodriguez M. Regulation of gene expression in protozoa parasites, Journal of Biomedicine and Biotechnology, ID 726045: 1-24, 2010.

doi: $10.1155 / 2010 / 726045$

[46] Maniatis T, Tasic B. Alternative pre-mRNA splicing and proteome expansion in metazoans, Nature, 418(6894): 236-242, 2002.

doi: $10.1038 / 418236 a$

[47] Gehring N, Wahle, E, Fischer U. Deciphering the mRNP code: RNA-bound determinants of post-transcriptional gene regulation, Trends in Biochemical Science, 42(5): 369-382, 2017.

doi: $10.1016 /$ j.tibs.2017.02.004

[48] De Gaudenzi J, Carmona S, Agüero F, Frasch A. Genomewide analysis of 3 '-untranslated regions supports the existence of post-transcriptional regulons controlling gene expression in trypanosomes, Peer J, 1(e118): 1-28, 2013.

doi: $10.7717 /$ peerj.118

[49] Shi Y. Alternative polyadenylation: New insights from global analyses, $\mathrm{RN} A, 18(12):$ 2105-2117, 2012.

doi: $10.1261 /$ rna.035899.112 
[50] Berkovits B, Mayr C. Alternative 3' UTRs act as scaffolds to regulate membrane protein localization. Nature, 522(7556):363$367,2015$.

doi: $10.1038 /$ nature14321

[51] Kramer S. Developmental regulation of gene expression in the absence of transcriptional control: The case of kinetoplastids, Molecular and Biochemical Parasitology, 181(2): 61-72, 2012.

doi: 10.1016/j.molbiopara.2011.10.002

[52] De Gaudenzi J, Noé G, Campo V, Frasch A, Cassola A. Gene expression regulation in trypanosomatids, Essays in Biochemistry, 51: 31-46, 2011.

doi: 10.1042/bse0510031

[53] Penalva L, Sanchez L. RNA binding protein sex-lethal (Sxl) and control of Drosophila sex determination and dosage compensation, Microbiol and Molecular Biology Reviews, 67(3): 343359, 2003.

doi: 0.1128/MMBR.67.3.343-359.2003

[54] Zearfoss N, Deveau L, Clingman C, Schmidt E, Johnson E, Massi F, Ryder S. A conserved three-nucleotide core motif defines musashi RNA-binding specificity, The Journal of Biological Chemistry, 289(51): 35530-35541, 2014.

doi: 10.1074/jbc.M114.597112

[55] Cragle C, MacNico A. Musashi protein-directed translational activation of target mRNAs is mediated by the poly(a) polymerase, germ line development defective-2, The Journal of Biological Chemistry, 289(20): 14239-14251, 2014.

doi: 10.1074/jbc.M114.548271 


\section{Caracterización de las regiones no traducidas ARN [UTR] de las isoformas de Trypanosoma cruzi LYT1 derivadas de un trans-empalme alternativo}

Resumen. En los trypanosomátidos, la expresión génica se regula principalmente en el nivel post-transcripcional mediante mecanismos basados en la interacción entre las proteínas de unión del ARN [RBP] y las figuras presentes en las regiones no traducidas [UTR] de las ARN, que en conjunto forman complejos ribonucleoproteicos [RNP] que definen el destino de la ARN. El pre-ARN derivado del gen LYT1 del Trypanosoma cruzi es procesado por trans-empalme alternativo, dando como resultado diferentes ARN que codifican las isoformas mLYT1 y kLYT1, proteínas con expresión diferencial, localización celular y función. El objetivo de este estudio fue caracterizar los 5' y 3’ UTR de las ARN LYT1 como el paso inicial hacia la identificación de los RPB responsables de la expresión diferencial. Se confirmó la presencia de los dos tipos de 5' UTR en dos aislantes del T. cruzi pertenecientes al DTU I; de esta forma también se comprobó la ocurrencia del trans-empalme alternativo en el gen LYT1 de este T. cruzi DTU. Además, por primera vez, se pudo demostrar la existencia de dos tipos de transcripciones de ARN LYT1, que difieren en longitud por 116 nts, y son generadas por poliadenilación alternativa. Adicionalmente, se realizó un análisis in-silico de la UTR obtenida experimentalmente, y otras diez secuencias LYT1 recuperadas de las bases de datos TritrypDB y GenBank, junto con una búsqueda exhaustiva de figuras estructuradas, mostrando una notable conservación de los figuras estructurales asociadas con el metabolismo del ARN en los diferentes UTR; estos elementos podrían estar implicados en la expresión diferenciada de la etapa específica de cada isoforma LYT1.

Palabras clave: Trypanosoma cruzi; Región no traducida [UTR]; Proteínas de unión de ARN [RBP]; Regulación de la expresión génica; gen LYT1. 


\section{Caracterização das regióes não-traduzidas do RNA [UTR] das isoformas de Trypanosoma cruzi LYT1 derivadas de uma junção trans-alternativa}

Resumo. Nos tripanossomatídeos, a expressão génica é regulada principalmente a nível pós-transcricional mediante mecanismos baseados na interação entre as proteínas de união do RNA [RBPs] e as fugiras presentes nas regiões não-traduzidas [UTRs] do RNA. O pré-RNA derivado do gene LYT1 do Trypanosoma cruzi é processado por uma junção trans-alternativa, resultando em diferentes RNA que codificam as isoformas mLYT1 e kLYT1, proteínas com expressão, localização celular e função diferenciadas. O objetivo de este estudo foi caracterizar as 5' e 3' UTRs dos RNAs LYT1 como sendo o passo inicial na identificação das RBPs responsáveis pela expressão diferenciada. A presença dos dois tipos de 5' UTRs foi confirmada em dois isolados de T. cruzi $i$ pertencentes ao DTU I; corroborando assim com a ocorrência da junção trans-alternativa no gene LYT1 de este T. cruzi DTU. Adicionalmente, se demonstrou pela primeira vez a existência de dois tipos de transcrições de RNA LYT1, que se diferenciam em comprimento por 116 nts, e são geradas por poliadenização alternativa. Além disso, realizou-se uma análise in-sílico da UTR obtida experimentalmente e outras dez sequencias LYT1 recuperadas das bases de dados TritrypDB e GenBank, junto com uma busca exaustiva de figuras estruturadas, mostrando uma notável conservação das figuras estruturais associadas com o metabolismo do RNA nas diferentes UTRs. Estes elementos poderiam estar envolvidos na expressão estágio-específica diferenciada de cada isoforma LYT1.

Palavras-chave: Trypanosoma crųi; região não-traduzida [UTR]; Proteínas de união de RNA [RBP]; Regulação da expressão génica; gene LYT1. 


\section{Elizabeth Ruiz Marvez}

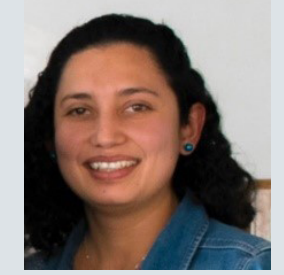

Biologist (Universidad del Tolima). MSc in Infections and Health in the Tropics (Universidad Nacional de Colombia). Currently, PhD candidate in Biological Sciences (Pontificia Universidad Javeriana. Bogota, Colombia). Research activities: molecular biology and medical entomology.

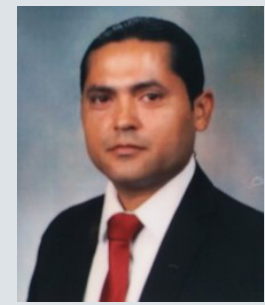

\section{Cesar A. Ramirez}

Biologist (Universidad del Tolima). PhD degree in Biological Science (Pontificia Universidad Javeriana. Bogota, Colombia). His skills include Molecular Biology, Proteomics and Bioinformatic. Currently, is working as Research Fellow at Mayo Clinic in Scottsdale.

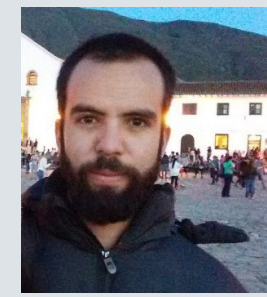

\section{Julian Camilo Casas}

Microbiologist (Pontificia Universidad Javeriana). MSc in Biological Science (Universidad de los Andes). The research areas of interest are microbial ecology and molecular biology.

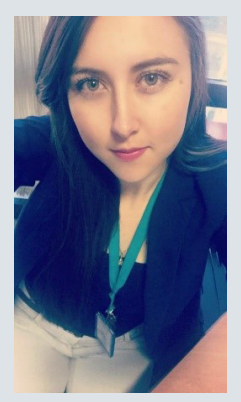

\section{Maria I. Ospina}

Bacteriologist (Pontificia Universidad Javeriana. Bogota, Colombia). Currently, is working on Ministerio de Salud y Protección Social (Bogota, Colombia). 


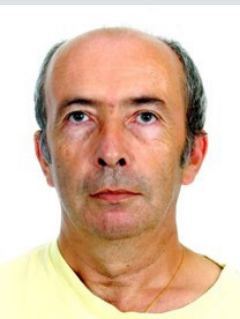

\section{Jose M. Requena}

PhD in Biology (Universidad Autónoma de Madrid). From 1998, associateprofessorin theMolecularBiology Department(UAM). Since 2003, group leader at the Centro de Biología Molecular Severo Ochoa (CBMSO, Spain). Research activities: regulation of gene expression in Leishmania, diagnosis and vaccine development for leishmaniasis. Additional information at http://www.cbm.uam.es/jmrequena

\section{Concepcion J. Puerta}

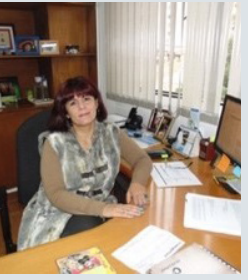

Bacteriologist with a doctoral degree in Biological Science (Universidad de Granada, Spain). Researcher in the fields of trypanosomatid molecular biology and human immune response to infections caused by these parasites. Currently, titular professor and Dean of the Science Faculty at Pontificia Universidad Javeriana (Bogota, Colombia). 